\title{
Habitat engineering by the invasive zebra mussel Dreissena polymorpha (Pallas) in a boreal coastal lagoon: impact on biodiversity
}

\author{
Anastasija Zaiko $\cdot$ Darius Daunys $\cdot$ Sergej Olenin
}

Received: 28 September 2007 / Revised: 21 March 2008 / Accepted: 19 April 2008 / Published online: 31 October 2008 (C) Springer-Verlag and AWI 2008

\begin{abstract}
Habitat engineering role of the invasive zebra mussel Dreissena polymorpha (Pallas) was studied in the Curonian lagoon, a shallow water body in the SE Baltic. Impacts of live zebra mussel clumps and its shell deposits on benthic biodiversity were differentiated and referred to unmodified (bare) sediments. Zebra mussel bed was distinguished from other habitat types by higher benthic invertebrate biomass, abundance, and species richness. The impact of live mussels on biodiversity was more pronounced than the effect of shell deposits. The structure of macrofaunal community in the habitats with $>10^{3} \mathrm{~g} / \mathrm{m}^{2}$ of shell deposits devoid of live mussels was similar to that found within the zebra mussel bed. There was a continuous shift in species composition and abundance along the gradient 'bare sediments-shell deposits-zebra mussel bed'. The engineering impact of zebra mussel on the benthic community became apparent both in individual patches and landscape-level analyses.
\end{abstract}

Keywords Ecosystem engineer - Keystone species · Alien species · Macrozoobenthos · Shell deposits · Benthic community $\cdot$ Mussel bed

\section{Introduction}

Zebra mussel Dreissena polymorpha is known as a powerful habitat engineer species in the most aquatic ecosystems

Communicated by K. Reise.

A. Zaiko $(\bowtie) \cdot$ D. Daunys $\cdot$ S. Olenin

Coastal Research and Planning Institute,

Klaipeda University, H. Manto 84,

92294 Klaipeda, Lithuania

e-mail: anastasija@corpi.ku.lt it has invaded (Nalepa and Fahnenstiel 1995; Olenin 1997; Stewart et al. 1998; Karatayev et al. 2002; Minchin et al. 2002; Vanderploeg et al. 2002). It alters habitats in both autogenic and allogenic way (sensu Jones et al. 1994), modifying the morphological and physical properties of sediments, extensively filtering suspended material and thereby affecting the availability of resources in ecosystem (Karatayev et al. 1997; Bially and MacIsaac 2000; Beekey et al. 2004; Hecky et al. 2004). Zebra mussel clumps (druses) are capable of increasing the colonisable benthic surface area (Botts et al. 1996; Stewart et al. 1998; Bially and MacIsaac 2000; Karatayev et al. 2002), providing the enemy- or stress-free space (Gutierrez et al. 2003; Beekey et al. 2004), controlling the transport of particles and solutes in the near-bottom environment (Gutierrez et al. 2003), altering boundary layer characteristics (Karatayev et al. 1994; Gutierrez et al. 2003), increasing the amount of organic material in the sediment by depositing feces and pseudofeces (Karatayev et al. 1994; Botts et al. 1996; Stewart et al. 1998; Karatayev et al. 2005), increasing dissolved nutrient concentrations via excretion or removing seston from the water column (Stewart et al. 1998; Karatayev et al. 2002; Rosemond and Anderson 2003). The latter two impacts can be classified as allogenic and are subsistent only to live mussels, whereas the others (autogenic) might be induced by spent shells as well.

This study was focused on autogenic habitat engineering aspects of $D$. polymorpha impact on benthic communities in a coastal lagoon's ecosystem. We estimated changes in abundances, species richness and community structure due to habitat alterations mediated either by living mussels or their shell deposits.

The Curonian lagoon was invaded by zebra mussel in the early 1800s (Olenin et al. 1999). Being able to form dense clumps and dominate the benthic community biomass, 
D. polymorpha became an important component of the lagoon's ecosystem (Olenin and Leppäkoski 1999). The direct pre- and post-invasion comparisons were not applicable here since zebra mussel invasion in the lagoon happened long before ecological research commenced. Therefore in our study we assessed the engineering impact of $D$. polymorpha referring to the control bottom sites, occupied neither by live mussels nor by their shell deposits. All the control sites were situated within the distribution area of zebra mussel in the Curonian lagoon.

\section{Methods}

Study area

The Curonian lagoon is a large $\left(1.584 \mathrm{~km}^{2}\right)$, shallow (mean depth $3.8 \mathrm{~m}$ ) and mainly freshwater body connected to the south-eastern part of the Baltic Sea by a narrow strait (Fig. 1). The Nemunas River brings $98 \%$ of the total freshwater runoff and enters the lagoon in its central area, dividing the water body into two different parts (Jurevicius 1959). The northern part is a transitory river-like system transporting freshwater into the sea and receiving seawater during wind-driven short-term inflow events. The lacustrine southern part is characterized by a relatively closed water circulation and lower current velocities. Therefore it serves as a main depositional area of the lagoon (Galkus and Jokšas 1997; Daunys et al. 2006).

The lagoon has a diverse benthic macrofaunal community with approximately 280 species recorded in the littoral zone (Zettler and Daunys 2007). Soft bottom of the northern part of the lagoon is characterized by oligochaetes, chironomids, and the invasive spionid Marenzelleria neglecta communities. The dominant bottom substrates are sand, silt, mud, and shell deposits (Trimonis et al. 2003).

The largest area occupied by zebra mussel community is located in the central part of the water body (Gasiunas 1959; Aristova 1965; Bubinas 1983; Olenin 1987, 1988, 1997). Few local patches of zebra mussel population are also found in the southern part of the lagoon, yet no quantitative data are available for these sites. Therefore the current study considered only zebra mussel community in the central part of the Curonian lagoon.

\section{Sampling design}

The quantitative characteristics of $D$. polymorpha population and macrozoobenthic communities were obtained from the results of two surveys performed in 1999 and 2006, using different sampling strategies (Fig. 1).

In 1999, sampling stations were distributed evenly in northern and central parts of the lagoon, in order to estimate the distribution patterns and area colonized by the zebra
Fig. 1 Distribution of zebra mussel bed and shell deposits in the central part of the Curonian lagoon with marked sampling sites: squares 1999 survey, rounded dots 2006 survey

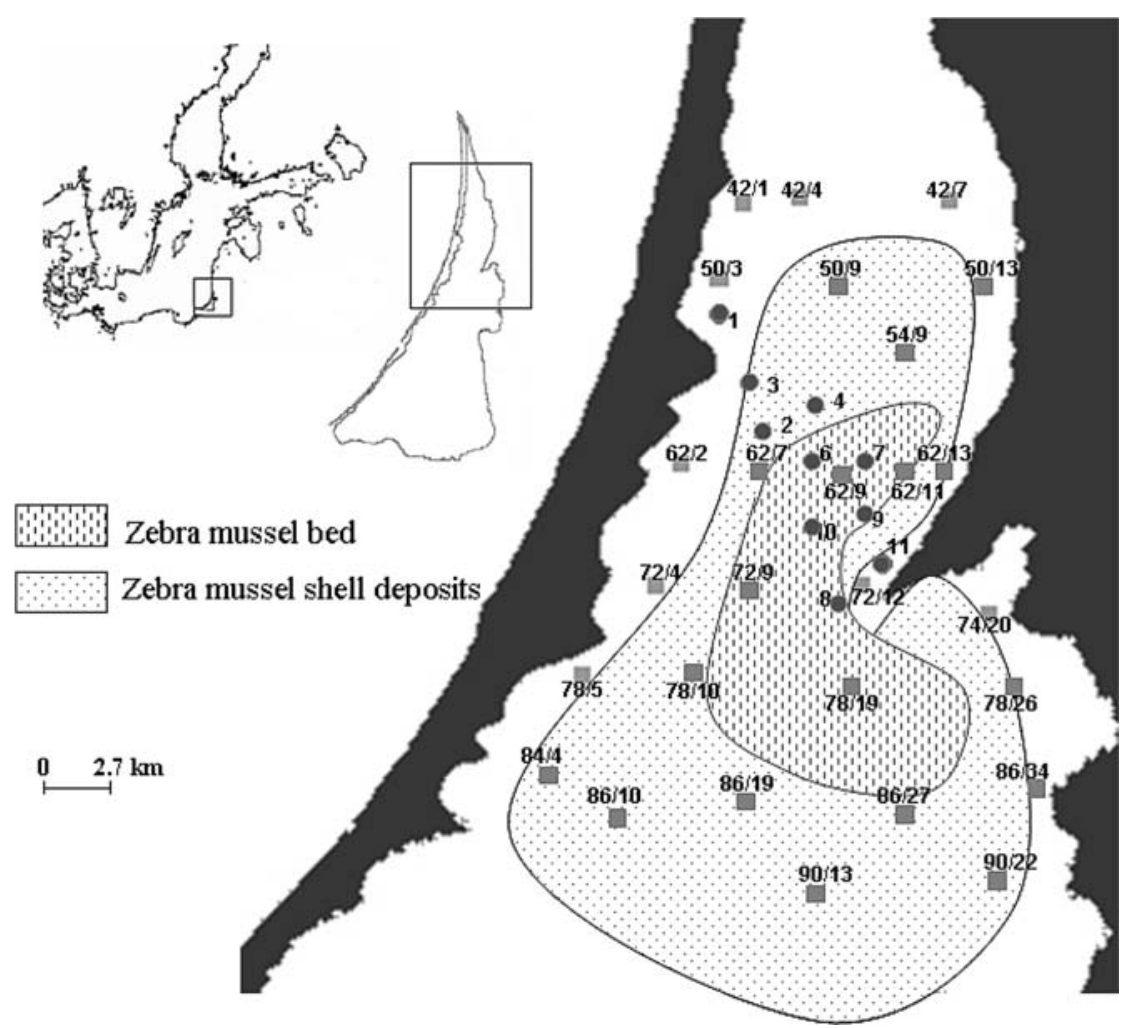


mussel community. In total, 27 sites were sampled with one replicate in each.

In 2006, the sampling was performed along the transect crossing the area occupied by zebra mussel population (Fig. 1) in order to obtain data along the shell deposits and zebra mussel biomass gradients and assess the small-scale habitat patchiness. In total, ten stations with three replicates in each were sampled.

All the samples were obtained from the sites with resembling depths $(2.6 \pm 1 \mathrm{~m})$ and hydrodynamic conditions.

A Van-Veen type grab (catch area $0.1 \mathrm{~m}^{2}$ ) was used for macrofauna sampling. Each sample was sieved $(1 \mathrm{~mm}$ mesh size) and preserved (4\% formaldehyde solution) on board. Once in the laboratory, the macrobenthic species were sorted out, identified, and counted using a binocular microscope, at $15 \times$ magnification. Wet weight was determined to within $0.001 \mathrm{~g}$. Samples were collected and treated following standard guidelines for bottom macrofauna sampling (HELCOM 1988). Along with the standard benthic samples treatment procedure, taxonomic identification of shell deposits (up to genus or species level if possible) was carried out. Then shell deposits of different taxonomic groups were dried and weighed separately.

\section{Classification of habitats}

Traditional techniques of underwater observations commonly used for classification of benthic habitats (e.g. remote underwater video or SCUBA diving) were not applicable in the Curonian lagoon, because of very low visibility (the Secchi depth is less than $0.5 \mathrm{~m}$ ). Thus the a priori identification of habitat type or its localization under existing conditions in the studied ecosystem could not be performed. Therefore the preliminary differentiation of habitats into 'bare sediments', 'zebra mussel shell deposits' and 'zebra mussel bed' was possible only after the onboard visual inspection of sampled material during the field sampling campaign, and more precisely-after the quantitative treatment of samples. Gradient analysis was performed in order to determine essential changes in species composition along the habitat gradient. For that purpose all species presence/absence data were ranged according to dry weight of shell deposits and log-transformed zebra mussel biomass. The appearance of species that have been observed only in live zebra mussel clusters or its shell deposits was analyzed.

After the quantitative treatment of samples, we ascertained that there was a number of species that tend to appear only in habitats modified either by live zebra mussels or its shell deposits. Those benthic invertebrates were not found in bare sediments (or only single specimens were observed). Thirteen species or higher taxons were subsistent for zebra mussel druses: Hydra vulgaris, Turbellaria,
Erpobdella octoculata, Glossiphonia complanata, G. concolor, G. heteroclita, Helobdella stagnalis, Eiseniella tetraedra, Viviparus viviparus, Asselus aquaticus, Corophidae, Pontogammarus spp., Trichoptera. The same species, except for $G$. complanata have been found in shell deposits as well. The presence/absence analysis of these species along zebra mussel biomass gradient has shown that they started to appear when zebra mussel biomass reached ca. 30 (Fig. 2) and corresponded to one mediumsized druse. All 13 species appear at $209 \mathrm{~g} / \mathrm{m}^{2}$ of zebra mussel biomass. Considering shell deposit gradient, all the subsistent for this habitat type species appear at $1,111 \mathrm{~g} / \mathrm{m}^{2}$ shells dry weight.

Therefore, 'zebra mussel bed' was distinguished by the biomass of live mussels exceeding $200 \mathrm{WWg} / \mathrm{m}^{2}$. 'Zebra mussel shell deposits' were characterized by the presence of spent shells in the amount of $1,000 \mathrm{DWg} / \mathrm{m}^{2}$ or more, with either no or very few (less than $200 \mathrm{WWg} / \mathrm{m}^{2}$ ) live zebra mussel therein. Finally, habitats with zebra mussel

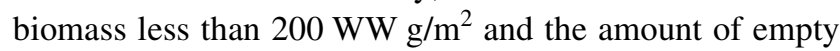
shells less than $1,000 \mathrm{DWg} / \mathrm{m}^{2}$, were classified as 'bare sediments' and treated as control sites (Table 1).

As soon as in natural environment a certain amount of empty shells is always found together with live mussels, in the case with 'zebra mussel bed' we considered zebra mussel biomass as a main determinative factor and did not take into account the shell deposits found therein.
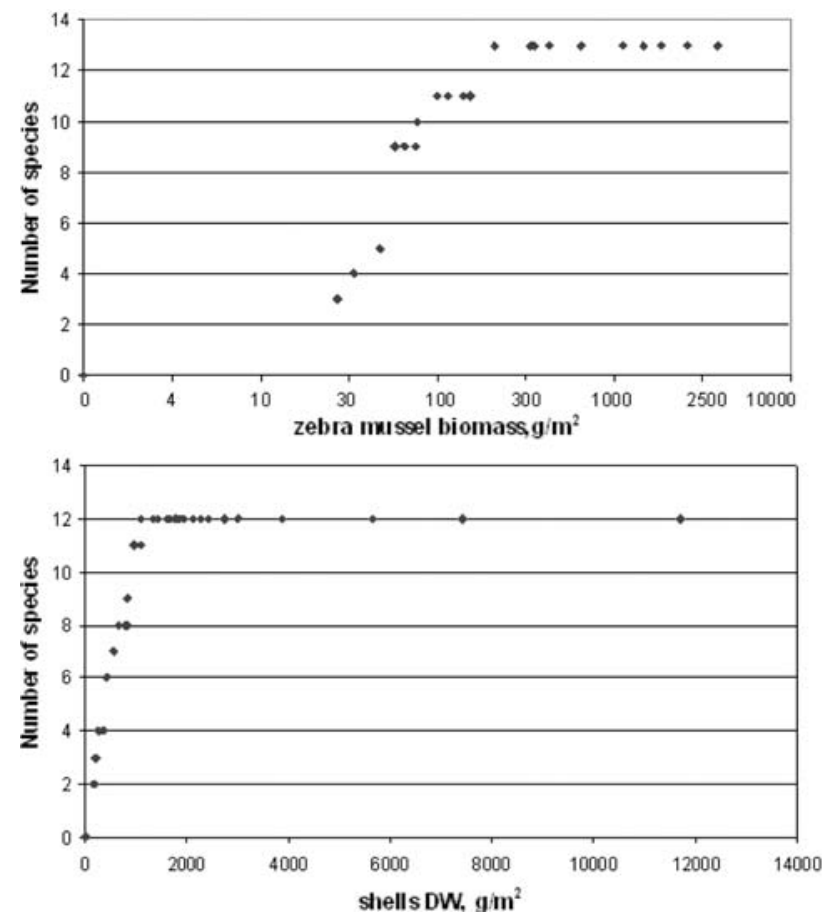

Fig. 2 Appearance of subsistent species along the log-transformed zebra mussel biomass (upper graph) and zebra mussel shells DW (lower graph) gradients 
Table 1 Classification of habitat types according to live zebra mussel biomass and dry weight of shell deposits

\begin{tabular}{lll}
\hline $\begin{array}{l}\text { Shell deposits } \\
\left(\mathrm{DWg} / \mathrm{m}^{2}\right)\end{array}$ & \multicolumn{2}{l}{ Zebra mussel biomass $\left(\mathrm{WWg} / \mathrm{m}^{2}\right)$} \\
\cline { 2 - 3 } & $0-200$ & $>200$ \\
\hline $0-1,000$ & Bare sediments & Zebra mussel bed \\
$>1,000$ & Shell deposits & \\
\hline
\end{tabular}

Data analysis

The distribution analysis of zebra mussel population and quantitative estimation of total zebra mussel biomass and amount of aggregated shell deposits in the Curonian lagoon was performed using Kriging interpolation method (Stein 1999 and references therein).

The impact of D. polymorpha on macrozoobenthos biodiversity was assessed comparing species richness, abundances, and biomass in two habitats modified by zebra mussel (zebra mussel bed and zebra mussel shell deposits) and control bottom sites (bare sediments). Therefore, species richness, abundance, and biomass were converted to $\mathrm{m}^{2}$ bottom surface area and treated as the response variables. Prior to the analysis, the abundance and biomass data were log-transformed to meet normality and homogeneity assumptions. Zebra mussel biomass was used as an explanatory variable and therefore was excluded from the total macrozoobenthos biomass.

The comparison of macroinvertebrate abundances in three analyzed habitat types-zebra mussel bed, shell deposits, and bare sediments-was accomplished using two-tailed non-parametric Kruskal-Wallis test, followed by a multiple rank test.

The macroinvertebrate community structure in the modified and unmodified habitats was compared using a nonmetric multidimensional scaling (MDS) procedure. To assess the benthic communities' differences in accordance with the habitat patchiness, and to find any patterns of macrofauna distribution concerned with engineering impact of zebra mussel, it was decided to use only 2006 data, since the sampling strategy was assumed to be more appropriate for this analysis.

Species abundance was related to zebra mussel biomass, amount of shell deposits, and environmental variablesdepth, distance to the sea, and sediment grain size, using redundancy analysis (RDA). In this case RDA was considered to be more appropriate than canonical correspondence analysis (CCA) since the most relationships between response and explanatory variables were approximately linear. Since the data from both (1999 and 2006) surveys were pooled together for this analysis, sampling year was included as an explanatory nominal variable.
Linear regression model was used to relate macroinvertebrate abundance to the living zebra mussel biomass and the amount of its shell deposits. All response variables were log-transformed to meet the normality assumption.

Confidence level of 0.05 was accepted for statistical tests to differentiate between statistically significant and random effects.

The statistical analyses were performed using Primer 5 for Windows ${ }^{\circledR}$, Brodgar (Highland Statistics Ltd.) and Statistica 6.0 $0^{\mathrm{TM}}$ (StatSoft) software.

\section{Results}

Identification and quantitative characteristics of habitats

According to the composition and amount of shell deposits as well as the biomass of zebra mussels, amongst the overall 57 samples taken during both surveys, 11 were classified as live zebra mussel bed, 17-as zebra mussel shell deposits, and 19-as bare sediments. Other ten sites (predominantly the ones from the western near-shore of the Curonian lagoon) were differentiated into a separate group "Valvata shell deposits", due to their specific substrate formed by shells of tiny Valvata spp. Gastropods (mainly $V$. piscinalis and $V$. pulchella), aggregated on the silty bottom $\left(>10^{3} \mathrm{gDW} / \mathrm{m}^{2}\right.$ Valvata shells).

The maximal amount of empty shells found in zebra mussel bed was $2.73 \times 10^{3} \mathrm{gDW} / \mathrm{m}^{2}$, in zebra mussel shell deposits-11.72 $\times 10^{3} \mathrm{gDW} / \mathrm{m}^{2}$. Zebra mussel biomass ranged from 0 to $3.8 \times 10^{3} \mathrm{~g} / \mathrm{m}^{2}$.

Due to extrapolation results, the assumed Curonian lagoon bottom area covered by zebra mussel shell deposits $\left(>1,000 \mathrm{~g} / \mathrm{m}^{2}\right)$ was ca. $400 \mathrm{~km}^{2}$. The area occupied by living zebra mussel bed ( $\left.>200 \mathrm{~g} / \mathrm{m}^{2}\right)$ was ca. $300 \mathrm{~km}^{2}$ (Fig. 1). Both areas were overlapping with a patchy structure within. The polygons shown on Fig. 1 indicate the most probable whereabouts of a certain habitat type. However, one could obtain local site zebra mussel shell accumulation or live zebra mussel druses almost all over the central part of the lagoon. As it was estimated, altogether, zebra mussel bed and its shell deposits covered about one-fourth of the lagoon area. The estimated total biomass of the living zebra mussels in the lagoon was about 140,000 t. The estimated total dry weight of accumulated shell deposits was ca. $600,000 \mathrm{t}$.

Macroinvertebrate community structure in the engineered versus control sites

There were about 40 species or higher taxa observed in the habitats modified by living zebra mussels or its empty shells (Table 2). Most of the species found in the habitats 
Table 2 Macroinvertebrate mean abundances (ind $/ \mathrm{m}^{2} ; \mathrm{SD}$ in parentheses) in three analyzed habitat types
* Statistically significant difference from one or both other groups, revealed from the Kruskal-Wallis and multiple rank tests

\begin{tabular}{|c|c|c|c|}
\hline \multirow[t]{2}{*}{ Taxon } & \multicolumn{3}{|l|}{ Habitat type } \\
\hline & Bare sediments & Zebra mussel bed & Shell deposits \\
\hline Hydra vulgaris & - & $30(74)^{*}$ & - \\
\hline Nematoda & - & $5(18)$ & $3(8)$ \\
\hline Turbellaria undet. & $15(26)$ & $78(105)^{*}$ & $6(12)$ \\
\hline Planaria torva & - & $1(3)$ & $1(2)$ \\
\hline Erpobdella octoculata & $117(169)$ & $242(276)$ & $357(1,117)$ \\
\hline Glossiphonia complanata & $8(20)$ & $212(456)^{*}$ & $6(12)$ \\
\hline G. concolor & - & $65(167)^{*}$ & - \\
\hline G. heteroclita & $58(143)$ & $459(1,206)^{*}$ & $18(43)$ \\
\hline Helobdella stagnalis & $111(140)$ & 49 (59) & $630(2,361)$ \\
\hline Oligochaeta & $3,382(2,914)$ & $3,516(3,566)$ & $2,790(3,749)$ \\
\hline Eiseniella tetraedra & $13(30)$ & $31(42)$ & $11(27)$ \\
\hline Marenzelleria neglecta & $5(17)$ & - & $2(6)$ \\
\hline Dreissena polymorpha & 87 (134) & $2,741(4,537)^{*}$ & $98(139)$ \\
\hline Pisidium spp. & $356(437)$ & $103(128)$ & $151(328)$ \\
\hline Sphaerium spp. & $9(15)$ & $8(24)$ & $6(12)$ \\
\hline Unionidae & $5(7)$ & $8(24)$ & $3(7)$ \\
\hline Bithynia tentaculata & $5(10)$ & $1(3)$ & $12(32)$ \\
\hline Lithoglyphus naticoides & - & $2(3)$ & $1(3)$ \\
\hline Radix ovata & - & - & $1(2)$ \\
\hline Theodoxus fluviatilis & - & $7(24)$ & $1(7)$ \\
\hline Valvata piscinalis & 157 (289) & 10 (19) & $103(236)$ \\
\hline V. pulchella & $2(6)$ & $1(3)$ & $1(4)$ \\
\hline Viviparus viviparus & - & $10(24)$ & $3(5)$ \\
\hline Argyroneta aquatica & - & - & $1(3)$ \\
\hline Hydrachnellae & $8(18)$ & $26(50)$ & $7(28)$ \\
\hline Ostracoda & $92(253)$ & $517(1,186)$ & $41(72)$ \\
\hline Asselus aquaticus & $2(6)$ & $171(234)^{*}$ & $1(2)$ \\
\hline Chelicorophium curvispinum & - & - & $1(2)$ \\
\hline Ch. multisetosum & - & $109(362)$ & $13(61)$ \\
\hline Ch. volutator & - & $3(10)$ & - \\
\hline Chaetogammarus warpachowskyi & $14(22)$ & $1(3)$ & $6(14)$ \\
\hline Pontogammarus crassus & $5(16)$ & $1(3)$ & $5(15)$ \\
\hline Pontogammarus robustoides & $5(12)$ & $1(3)$ & $4(17)$ \\
\hline Gammaridae undet. & $9(26)$ & - & $3(9)$ \\
\hline Corixidae & - & $2(5)$ & $1(3)$ \\
\hline Argulus foliceus & - & - & $1(3)$ \\
\hline Musidae & - & - & $1(2)$ \\
\hline Chironomidae & $1,685(1,164)$ & $1,347(944)$ & $1,098(1,507)$ \\
\hline Trichoptera & $7(13)$ & $12(23)$ & $6(10)$ \\
\hline
\end{tabular}

altered by zebra mussels were present also in the bare sediments, but in lower abundances. However, there were a number of organisms, like $H$. vulgaris, Nematoda, Planaria torva, Glossifonia concolor, Lithoglyphus naticoides, Radix ovata, Theodoxus fluviatilis, V. viviparus, Argyroneta aquatica, Chelicorophium curvispinum, Ch. multisetosum, Ch. volutator, Corixidae, Argulus foliceus, Musidae, and Corixidae observed exceptionally in the habitats engineered by zebra mussel. On the other hand, there were only few species (e.g. Chaetogammarus warpachowskyi, Pisidium spp., Valvata piscinalis, chironomids) which reached higher abundances in bare sediments, when compared to the modified ones. However, no statistically significant difference from other groups was obtained for these invertebrates (Table 2). None of the species unique for bare sediments were found. 
Fig. 3 RDA biplot for logtransformed species abundances with shell dry weight mass (zebra_biomass), depth, medium sediment grain size (Md), distance to the sea (distance_to_sea) and year of sampling (year) as explanatory variables. For the better perception, only species revealing any relation to the analyzed factors are shown (zm_shells), zebra mussel bio-

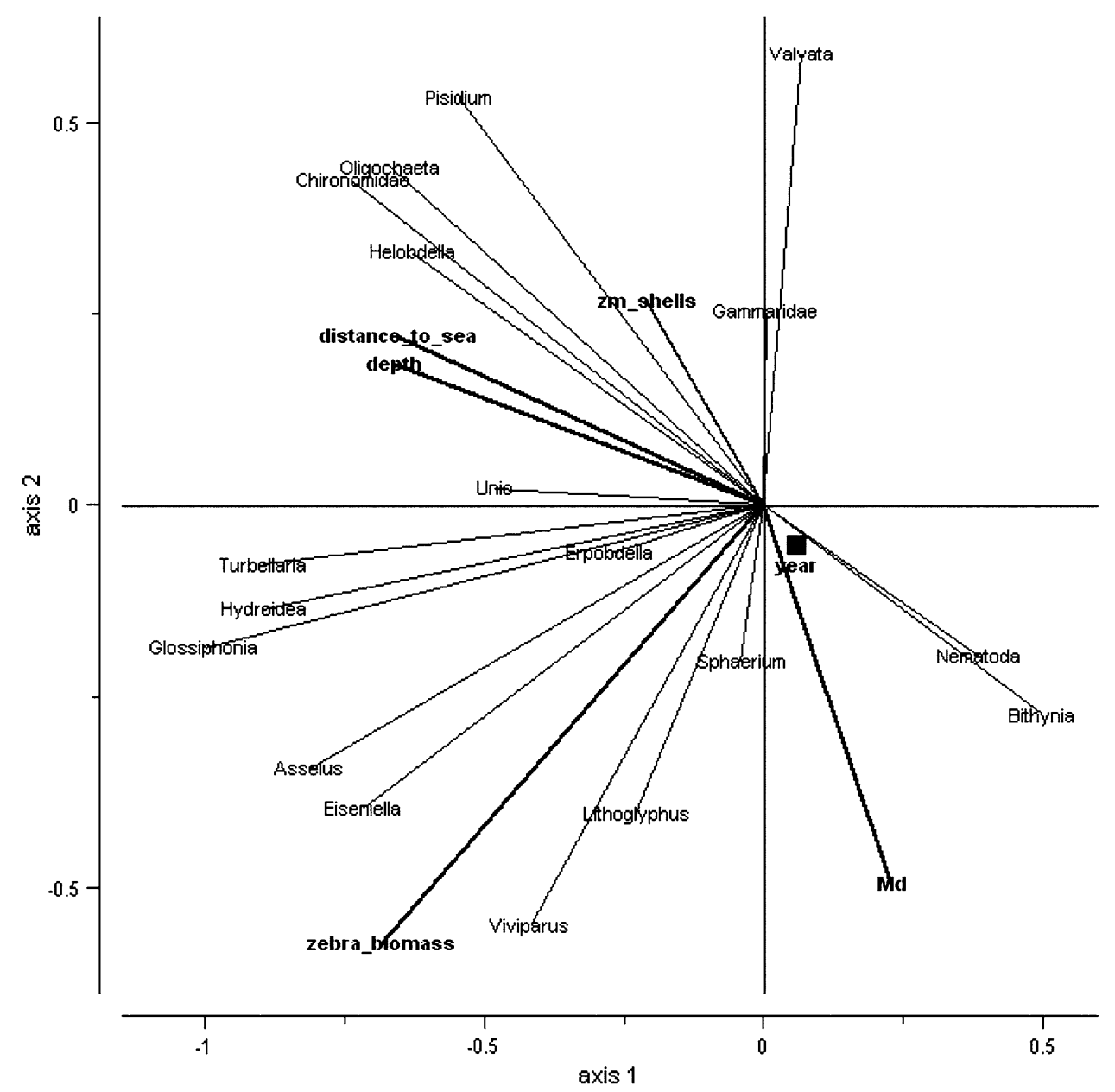

The RDA showed that there was a number of macroinvertebrates positively correlated with zebra mussel biomass (e.g. Hydroidea, Turbellaria, Glossiphonia spp., E. octoculata, E. tetraedra, V. viviparus, L. naticoides, A. aquaticus, etc.) (Fig. 3). H. stagnalis, unionids, oligochaets, and chironomids were related to the depth variable and, consequently to the salinity gradient (expressed as a distance to the sea), and the amount of zebra mussel shell deposits, since these three variables indicated a positive correlation. Two taxa (Bithynia and Nematoda) were positively related to the sediment medium grain size and the year of sampling. Pisidium, Valvata and Gammaridae species were mostly related to the amount of shell deposits.

Bigger amounts of zebra mussel shells tend to occur at higher depths and finer sediments. The sediment grain size was negatively related to the depth and amount of empty shells. Zebra mussel biomass and amount of empty shells in the sediments has not shown any association on the presented RDA biplot. The nominal sampling year factor positively correlated with sediment grain size and negativelywith depth and distance to the sea. This might be the result that in 2006 samples were taken further north than during the 1999 survey. The correlations of the year factor with other response or explanatory variables were not considerable.

Three physical variables, zebra mussel biomass, and the amount of zebra mussel shell deposits explained $25 \%$ of the variation in invertebrate abundances. The two-dimensional approximation explained $70 \%$ of this $(52.7 \%$ on axis 1 and $17.3 \%$ on axis 2 ).

Analysis of data obtained in 2006 revealed a gradient in benthic community structure caused by alteration of a habitat type (Fig. 4). Six samples, distinct from all others, referred to the sediments modified by the small snail Valvata shell deposits. The samples from bare sediments, zebra mussel shell deposits, and living zebra mussel bed formed a blend with shell deposits in intermediate position.

The differentiation of the habitats is rather clear, yet several samples (3/3_s, 4/3_s, 7/1_s), taken in the habitat defined as zebra mussel shell deposits, pooled into zebra mussel bed. All these samples are characterized by comparatively high amount of empty shells (ca. 2,000 g/m ${ }^{2}$ ) and absence of live zebra mussels.

The linear regression model marked out species having statistically significant positive correlation with zebra mussel biomass, thereby defining the specific "zebra mussel bed 


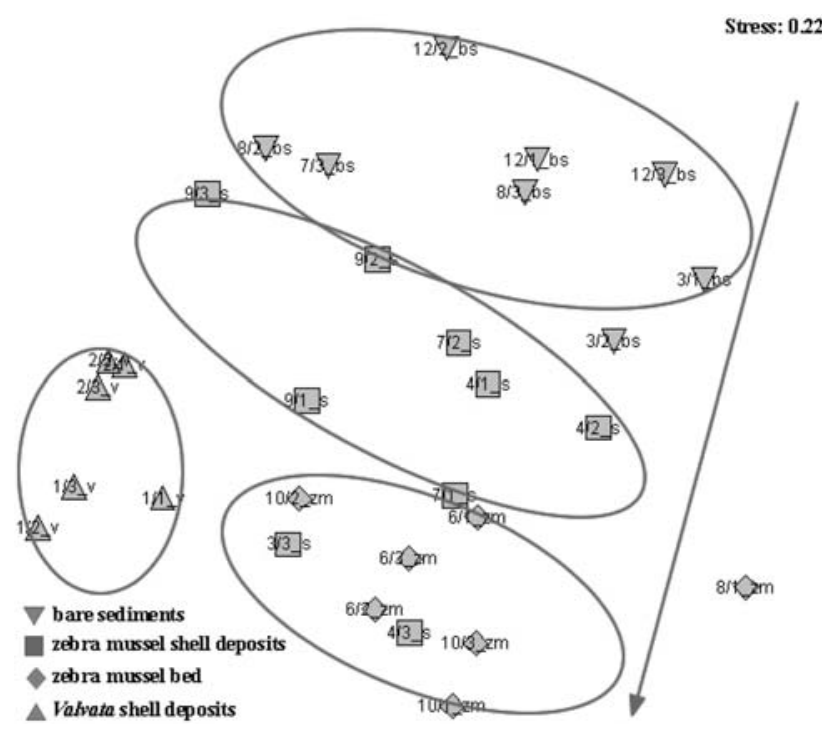

Fig. 4 Similarity in macrozoobenthos community structure in different habitats. The gradient line shows direction from bare sediments to zebra mussel bed. The figures indicate sample code (station number/ replicate number)

community". This community formed in the benthic habitat when live zebra mussel biomass attained ca. $200 \mathrm{~g} / \mathrm{m}^{2}$ (i.e. the assumption made in our definition of "zebra mussel bed" is true) (Fig. 5). Still we could not ignore the "shell deposits" factor assessing the macrozoobenthos distribution. As it followed from our analysis, the macrofauna community, typical to zebra mussel bed, tended to appear even devoid of live $D$. polymorpha druses, when there was a sufficient amount of empty shells on the bottom $\left(>1,000 \mathrm{~g} / \mathrm{m}^{2}\right)$ (Fig. 4). The two leeches E. octoculata and H. stagnalis distinguished the "zebra mussel shell deposits community" as their abundances had statistically significant positive correlation with the dry weight of shell deposits on the bottom.

\section{Discussion}

The major obstacle we have confronted with was the impossibility of applying the stratified sampling design, which would give the best fit to our study and ensure that the major habitat types are included in the sample. Due to the high turbidity of water we could not make any a priori choice for cluster sampling (using remote video or SCUBA diving), so the systematic sampling was considered to be the best (and likely the only appropriate) option for the benthic habitat study in the Curonian lagoon. Yet such a "blind" sampling method forced us to apply an a posteriori habitat classification, based on the results of quantitative analysis of samples. This has brought a certain extent of circularity into our approach. The only possible way to overcome this problem under the given circumstances is to plan some kind of field experiment, when defined in advance bottom areas are manipulated by a researcher, with removed or added mussels and shells accordingly. Still the aim of the current study was to gain some insight of the natural benthic modified and unmodified habitats of the lagoon and communities therein, so the experimental approach was not accepted as appropriative in this case.

The thresholds for distinction of natural habitats modified either by live zebra mussels or their shell deposits, determined in our study should be emphasized likely as the most important result. In an ecosystem with a heterogeneous benthic environment it is hard to obtain any valid arguments to distinguish among different habitat types. In the Curonian lagoon benthic species composition has proved to be such a distinctive factor, sufficient to differentiate between zebra mussel bed, zebra mussel shell deposits, and bare sediments.

In the context of the estimated amount of zebra mussel shell deposits, accumulated on the soft bottom of the Curonian lagoon (about 600,000 t), their significance as habitat engineering agent becomes more apparent. The typical
Fig. 5 The presence/absence of species, typical for zebra mussel bed or shell deposits, corresponding to the zebra mussel biomass (on the right) and amount of shell deposits (on the $l e f t$ ). For shell deposits only samples devoid of live mussels were analyzed. Only species with statistically significant correlation of abundance with either zebra mussel biomass or dry weight of shell deposits are presented (correlation coefficients are shown next to genus name)
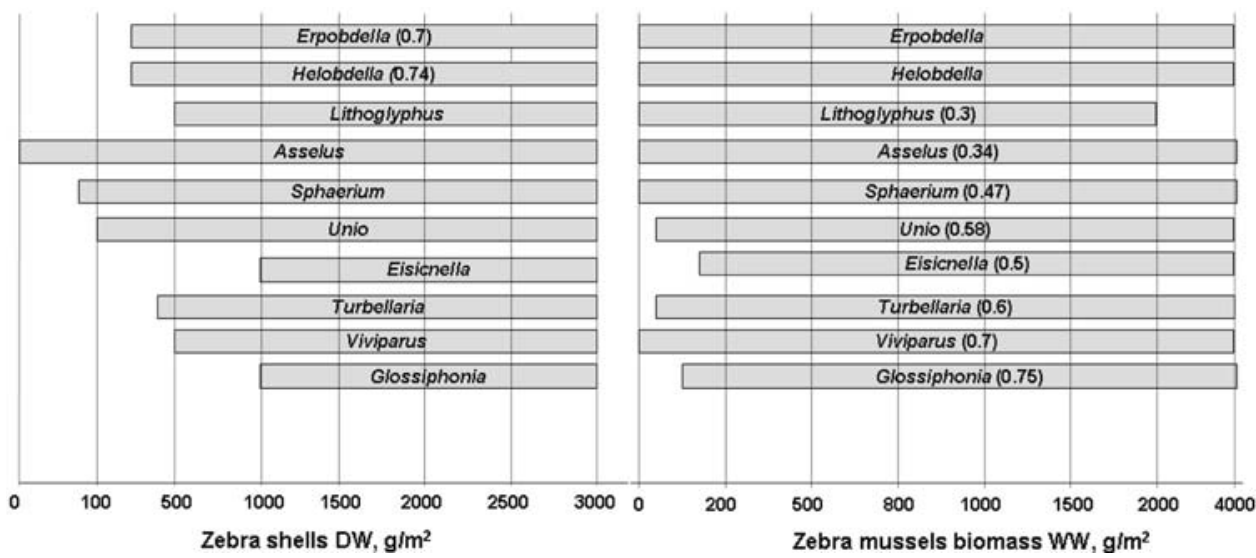
calcium carbonate production rates for $D$. polymorpha ranges from 10 to $10,000 \mathrm{gDW} / \mathrm{m}^{2}$ year, depending on the population size (Strayer and Malcom 2007). Based on this, the density of calcite and aragonite, assuming shells have a calcite/aragonite ratio of 1:1 (Gutierrez et al. 2003), zebra mussels may deposit $0.035-3.5 \mathrm{~mm}$ of $\mathrm{CaCO}_{3}$ per year. This is rather high given that recent annual sedimentation rate in Curonian lagoon is about $3.2 \mathrm{~mm}$ (Pustelnikovas 1995). The shell material can persist for a long time after the mussel dies. The durability of shells and their occurrence at high densities are characteristics that increase the likelihood of important engineering effects over large temporal and spatial scales (Kidwell 1985; Gutierrez et al. 2003). Thus zebra mussel is capable of maintaining its autogenic engineering impact even if complete extinction of the population occurs in an ecosystem.

The MDS analysis evidenced that habitat formed by zebra mussel shell deposits maintain benthic communities different from those common in bare sediments. Although this difference is not as pronounced as between the bare sediment community and living zebra mussel bed (Fig. 4).

But the main argument for the importance of empty shells as ecosystem engineering agent is the fact that typical "zebra mussel bed community" in the lagoon might occur even devoid of living zebra mussel druses, if a certain amount of empty shells persisted in the bottom.

As it has been reported earlier (Karatayev et al. 1997, 2002; Bially and MacIsaac 2000; Reed et al. 2004), zebra mussels in soft-bottom environments provide substrata for the epifaunal invertebrates that are normally unable to attach to bare sediments. On the other hand, mussel beds on the soft bottom should not have much impact on the infaunal species, because these organisms are capable to survive and shelter in the ambient sediments (Gutierrez et al. 2003). The results of our study support this statement, since invertebrates correlated with zebra mussel biomass in the Curonian lagoon are predominantly epifaunal organisms (Hydroidea, Glossiphonia spp., V. viviparus, L. naticoides, A. aquaticus), which likely take advantage of both structural complexity and resources provided by zebra mussel druses. The carnivorous species (like leeches) also benefit from the resource availability enhanced by zebra mussel (easily accessible preys sheltered in druses or empty shells), as it was verified by RDA and Pearson's R. All the organisms observed exclusively in habitats modified either by living mussels or empty shells (H. vulgaris, G. concolor, L. naticoides, $R$. ovata, T. fluviatilis, Viviparus viviparous, C. curvispinum, Ch. multisetosum, Ch. volutator, Pontogammarus robustoides, etc.) also were the epifaunal ones.

Abundances of chironomids and oligochaets (common infaunal invertebrates on the soft bottom of the Curonian lagoon) did not differ much between the bare bottom and sediments modified by zebra mussel. Yet the reported num- bers of these organisms in the samples from zebra mussel bed were not obtained from the 'real sediments', but from the druses covering the bottom. It means that in this case the infaunal organisms were functioning as epifaunal ones to a certain extent.

The RDA revealed a positive correlation between the depth and the amount of empty shells therein. It means that shell deposits not necessarily accumulate in the areas occupied by living zebra mussel bed, but transported with hydraulic flows toward the bottom depressions. This might be confirmed also by the fact that both depth and shell deposits factors in RDA showed strong negative correlation with sediment grain size variable, i.e. fine sedimentary particles also tend to sink in these bottom cavities, where favorable hydrodynamic conditions for sedimentation occur. It is likely that increased roughness of the bottom, induced by protruding shell aggregations, may locally promote sedimentation process in these areas (the particle trapping effect). Yet, in the context of the Curonian lagoon depth should not be considered as a driving factor in the distribution of benthic communities, as there are no substantial depth differences, at least in the northern part of the water body. The impact we had obtained most probably refers to a local bottom depressions or eminences with depths deviating from the average not more than by $1.5 \mathrm{~m}$.

The replicate samples taken at each station in 2006 survey have represented the bottom patchiness within the area of ca. $50 \mathrm{~m}^{2}$. The replicates from the station 3,7 , and 8 exemplified the patchiness of the bottom within the zebra mussel distribution area (Fig. 4). These samples were assigned to different habitat types according to the amount of shells and zebra mussel biomass. Moreover, they were distinct by their benthic fauna composition and abundances, what was clearly reflected in MDS results.

Jones et al. (1997) emphasized the importance of spatial scale in predicting the effects of ecosystem engineers on biodiversity. According to this hypothesis, at the patch level, i.e. comparing species richness in individual engineered patches and individual unmodified patches, the obtained engineering impact might be tenuous. In the current study we did not treat species richness as the main index of engineering effect, but the complex of variables (species composition and abundances). Thus it let us to obtain the differences among individual patches as well, and to show the propriety of the applied 'patch-to-patch' analysis. This approach has also revealed the ability of zebra mussel to affect the distribution of species by changing the resource availability at a site of its direct occurrence (not necessarily at a large 'Dreissena reef'), and form some sort of "oases" of structural and biological diversity in the benthic environment of the Curonian lagoon.

Vitousek (1990) noted that invasive engineer species have much larger effects on their new community than 
non-engineer species, since both biological and physical characteristics of the environment will be altered. On the other hand, the combination of invasive species and habitat modification is often considered as a presage for new invasions (Cuddington and Hastings 2004). In our earlier study, among different habitats of the SE Baltic Sea region, habitats altered by zebra mussel yielded in invasiveness only to anthropogenically disturbed habitats (Zaiko et al. 2007). In this sense the significance of zebra mussel engineering impact becomes even more apparent and relevant for the future research.

Acknowledgments This study was supported by the EU FW6 Integrated Project 506675 ALARM "Assessing Large-scale environmental risks with tested methods" and EU FW6 Contract No. 505406 MARBEF "Marine Biodiversity and Ecosystem Functioning".

\section{References}

Aristova GI (1965) The Kurskij Gulf benthos. In: Proc. AtlantNIIRO. Kaliningrad 14:19-39 (in Russian)

Beekey MA, McCabe DJ, Marsden JE (2004) Zebra mussels affect benthic predator foraging success and habitat choice on soft sediment. Oecologia 141:164-170

Bially A, MacIsaac HJ (2000) Fouling mussels (Dreissena spp.) colonize soft sediments in Lake Erie and facilitate benthic invertebrates. Fresh Biol 43:85-97

Botts PS, Patterson BA, Schloesser DW (1996) Zebra mussel effect on benthic invertebrates: physical or biotic? J North Am Benthol Soc 15(2):179-184

Bubinas A (1983) Zoobenthos. In: Gudelis V, Pustelnikov O (eds) Biogeochemistry of the Kuršių Gulf. Vilnius: 44-59 (in Russian with English summary)

Cuddington K, Hastings A (2004) Invasive engineers. Ecol Modell 178:335-347

Daunys D, Zemlys P, Olenin S, Zaiko A, Ferrarin C (2006) Impact of the zebra mussel Dreissena polymorpha invasion on the budget of suspended matter in a shallow lagoon ecosystem. Helgol Mar Res 60(2):113-120

Gasiunas I (1959) Forage macrozoobenthos of the Kuršiu Marios. In: Jankevicius K, Gasiunas I, Gediminas A, Gudelis V, Kublickas A, Maniukas I (eds) Kursiu Marios. Lithuanian Academy of Sciences, Vilnius, pp 191-292 (in Russian)

Galkus A, Jokšas K (1997) Sedimentary material in the transitional aquasystem. Institute of Geography, Vilnius, p 198 (in Lithuanian with English summary)

Gutierrez JL, Jones CG, Strayer DL, Iribarne OO (2003) Mollusks as ecosystem engineers: the role of shell production in aquatic habitats. Oikos 101:79-90

Hecky RE, Smith REH, Barton DR, Guilford SJ, Taylor WD, Charlton MN, Howell T (2004) The nearshore phosphorus shunt: a consequence of ecosystem engineering by dreissenids in the Laurentian Great Lakes. Can J Fish Aquat Sci 61:1285-1293

HELCOM (1988) Guidelines for the Baltic monitoring programme for the third stage. Part D, biological determinants, pp 23-28

Jones CG, Lawton JH, Shachak M (1994) Organisms as ecosystem engineers. Oikos 69(3):373-386

Jones CG, Lawton JH, Shachak M (1997) Positive and negative effects of organisms as physical ecosystem engineers. Ecology 78:19461957
Jurevicius R (1959) Hydrodynamic conditions in the Curonian Lagoon. In: Jankevicius K, Gasiunas I, Gediminas A, Gudelis V, Kublickas A, Maniukas I (eds) Kursiu Marios. Lithuanian Academy of Sciences, Vilnius, pp 69-108

Karatayev AY, Lyakhnovich VP, Afanasiev SA, Burlakova LE, Zakutsky VP, Lyakhov SM, Miroshnichenko MP, Moroz TG, Nekrasova MY, Skalskaya IA, Kharchenko TG, Protasov AA (1994) The place of species in ecosystem. In: Starobogatov JI (ed) Freshwater Zebra Mussel Dreissena polymorpha (Pall.) (Bivalvia, Dreissenidae). Systematics, Ecology, Practical Meaning, Nauka Press, Moscow, pp 206-221 (in Russian)

Karatayev AY, Burlakova LE, Padilla DK (1997) The effects of Dreissena polymorpha (Pallas) on aquatic communities in Eastern Europe. J Shell Res 16(1):187-203

Karatayev AY, Burlakova LE, Padilla DK (2002) Impacts of zebra mussels on aquatic communities and their role as ecosystem engineers. In: Leppäkoski E, Gollasch S, Olenin S (eds) Invasive aquatic species of Europe-distribution, impact and management. Kluwer, Dordrecht, pp 433-446

Karatayev AY, Burlakova LE, Padilla DK (2005) Contrasting distribution and impacts of two freshwater exotic suspension feeders, Dreissena polymorpha and Corbicula fluminea. In: Dame RF, Olenin S (eds) The comparative roles of suspension-feeders in ecosystems. NATO science series IV: earth and environmental sciences, vol 47. Springer, Dordrecht, pp 239-262

Kidwell SM (1985) Palaeobiological and sedimentological implications of fossil concentrations. Nature 318:457-460

Minchin D, Lucy F, Sullivan M (2002) Zebra mussel: impacts and spread. In: Leppäkoski E, Gollasch S, Olenin S (eds) Invasive aquatic species of Europe-distribution, impact and management. Kluwer, Dordrecht, pp 135-146

Nalepa TF, Fahnenstiel GL (1995) Dreissena polymorpha in the Saginaw Bay, Lake Huron ecosystem: overview and perspective. J Great Lakes Res 21(4):411-416

Olenin S (1987) Zoobenthos of the Curonian Lagoon: results of biological monitoring, 1980-1984. In: Simonov A, Agarova I (eds) Chemistry and biology of seas. Proc. State Oceanographic Institute. Moscow Hydrometeoizdat publ.:175-191 (in Russian)

Olenin S (1988) Some aspects of biocenotic and trophological structure of the bottom fauna in the Curonian Lagoon. Reg Hydrometeorol (Vilnius) 12:46-55 (in Russian with English summary)

Olenin S (1997) Comparative study of the south-eastern Baltic coastal zone and the Curonian Lagoon bottom communities. In: Andrushaitis A (ed) Proceedings of the 13th Baltic marine biologists symposium. Institute of Aquatic Ecology, University of Latvia, Riga, pp 151-159

Olenin S, Leppäkoski E (1999) Non-native animals in the Baltic Sea: alteration of benthic habitats in coastal inlets and lagoons. Hydrobiologia 393:233-243

Olenin S, Orlova M, Minchin D (1999) Dreissena polymorpha (Pallas, 1771). In: Gollasch S, Minchin D, Rosenthal H, Voigt M (eds) Case histories on introduced species: their general biology, distribution range expansion and impact. Logos-Verlag, Berlin, pp $37-$ 42

Pustelnikovas O (1995) The geology of Kurskiy Marios Lagoon and Future Development of the Lithuanian Coastal Zone. Directions in European Coastal Management, pp 533-539

Stewart TW, Miner JG, Lowe RL (1998) Quantifying mechanisms for zebra mussel effects on benthic macroinvertebrates: organic matter production and shell-generated habitat. J North Am Benthol Soc 17(1):81-94

Reed T, Wielgus SJ, Barnes AK, Schiefelbein JJ, ana Fettes AL (2004) Refugia and local controls: benthic invertebrate dynamics in Lower Green Bay, Lake Michigan following zebra mussel invasion. J Great Lakes Res 30(3):390-396 
Vanderploeg HA, Nalepa TF, Jude DJ, Mills EL, Holeck KT, Liebig JR, Grigorovich IA, Ojaveer H (2002) Dispersal and emerging ecological impacts of Ponto-Caspian species in the Laurentian Great Lakes. Can J Fish Aquat Sci 59:1209-1228

Rosemond AD, Anderson CB (2003) Engineering role models: do nonhuman species have the answers? Ecol Eng 20:379-387

Stein ML (1999) Interpolation of spatial data: some theory for Kriging. Springer, Berlin, p 247

Strayer DL, Malcom HM (2007) Shell decay rates of native and alien freshwater bivalves and implications for habitat engineering. Fresh Biol. doi:10.111/j.1365-2427.2007.01792.x
Trimonis E, Gulbinskas S, Kuzavinis M (2003) The Curonian lagoon bottom sediments in the Lithuanian water area. Baltica 16:13-20 Vitousek PM (1990) Biological invasions and ecosystem processes: towards an integration of population biology and ecosystem studies. Oikos 57:7-13

Zaiko A, Olenin S, Darius D, Nalepa T (2007) Vulnerability of benthic habitats to the aquatic invasive species. Biol Invasions 9:703-714

Zettler M-L, Daunys D (2007) Long-term macrozoobenthos changes in a shallow boreal lagoon: comparison of a recent biodiversity inventory with historical data. Limnologica 37:170-185 